\title{
Haploidentical Stem Cell Transplantation with Post-Transplant Cyclophosphamide in pediatric refractory Langerhans cell histiocytosis: a case Report
}

vipin khandelwal ${ }^{1}$, sanjeev sharma ${ }^{1}$, Dharma Choudhary ${ }^{2}$, divya doval ${ }^{2}$, SAROJ BALA $^{1}$, anil handoo ${ }^{1}$, rasika setia ${ }^{1}$, and Alka Kumar ${ }^{1}$

${ }^{1}$ B L K SUPERSPECIALITY HOSPITAL

${ }^{2}$ BLK Superspeciality Hospital

July 29, 2020

\begin{abstract}
Children with multisystem - Langerhans cell histiocytosis (MS-LCH) that fails to respond to conventional chemotherapy have poor outcomes. Hematopoietic stem cell transplant (HSCT) represents a potential salvage approach. We report a first case of successful haploidentical transplantation in one child with refractory MS-LCH using T cell replete graft and post transplant Cyclophosphamide (PT-CY) from father as a donor. On last follow up he is 21 months post transplant with no signs of disease activity. This case report suggests that T-cell replete haploidentical donor transplantation using PTCY is a feasible and successful curative option for Patients with refractory MS-LCH who have no matched donor.
\end{abstract}

\section{Hosted file}

Manuscript . doc available at https : //authorea.com/users/347167/articles/472955-haploidenticalstem-cell-transplantation-with-post-transplant-cyclophosphamide-in-pediatric-refractorylangerhans-cell-histiocytosis-a-case-report 


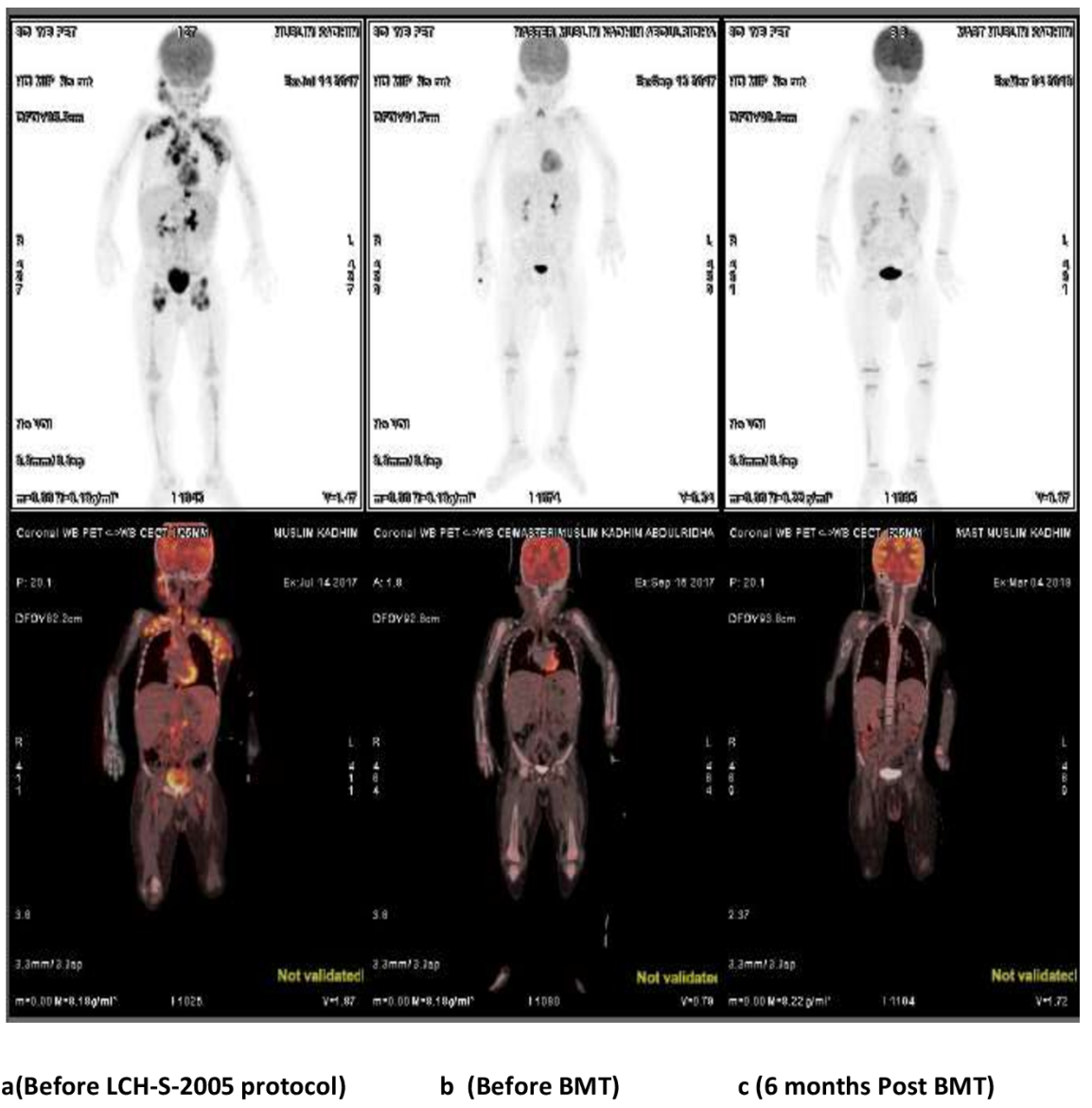




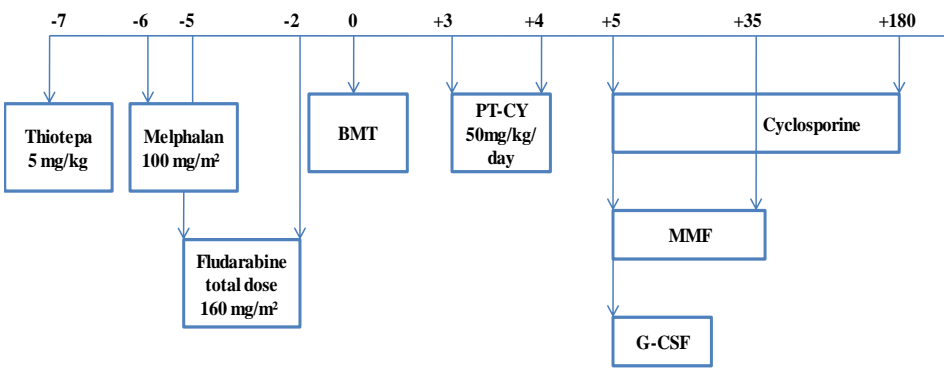

